九州大学学術情報リポジトリ

Kyushu University Institutional Repository

Record of Haemaphysalis flava Neumann (Acari, Ixodidae) from Zoothera dauma (Latham) (Aves) in Kyushu, Japan

Yamauchi, Takeo

Takeno, Koichi

https://doi.org/10.5109/2647

出版情報: ESAKIA. 40，pp.99-101，2000-03-31. Entomological Laboratory，Faculty of Agriculture， Kyushu University

バージョン：

権利関係 : 
ESAKIA, (40): 99 - 101. March 31, 2000

\title{
Record of Haemaphysalis flava Neumann (Acari, Ixodidae) from Zoothera dauma (Latham) (Aves) in Kyushu, Japan')
}

\author{
Takeo YaMAUCHI \\ Biosystematics Laboratory, Graduate School of Social and Cultural Studies, \\ Kyushu University, Ropponmatsu, Fukuoka, 810-8560 Japan \\ and \\ Koichi TAKENO \\ Hikosan Biological Laboratory, Faculty of Agriculture, \\ Kyushu University, Hikosan, 824-0721 Japan
}

\begin{abstract}
Key words: tick, Haemaphysalis flava, Zoothera dauma, distributional record, host record, Japan.
\end{abstract}

Ticks feeding on vertebrate's blood are of medical and veterinary importance because they are vectors for various diseases. Knowledge of host associations and fauna is therefore essential in studying the tick-borne diseases and in tick-control efforts.

On March 19, 1981, Koichi Takeno (the junior author) found a White's thrush, Zoothera dauma (Latham, 1790) just after death caused by collision with a windowpane on the grounds of Hikosan Biological Laboratory, Kyushu University. Moreover, he collected a nymph of Haemaphysalis flava Neumann, 1897 attached to the bird. This is the second record of $H$. flava from $Z$. dauma.

Haemaphysalis flava is distributed in Hokkaido, Honshu, Shikoku, Kyushu, and Korea. It is considered a parasite of a number of mammal and bird hosts (Yamaguti, et al., 1971). Records of $H$. flava from birds are shown in Table 1.

Asanuma et al. (1955) first recorded $Z$. dauma à a host of nymphal $H$. flava without the site of capture specified. They described that birds were parasitized only by immature forms, but mammals by all stages. Our observation was also consistent with their description.

\section{Acknowledgments}

We wish to express our sincere thanks to Assoc. Prof. O. Yata and Dr. B. J. Sinclair of Biosystematics Laboratory, Graduate School of Social and Cultural Studies, Kyushu University (BLKU) for their critical reading of the manuscript. We also express

1) Contribution from the Biosystematics Laboratory, Graduate School of Social and Cultural Studies, Kyushu University (No. 53). 
Table 1. Records of Haemaphysalis flava from birds. Host [Japanese name] References

Order Falconiformes Accipitridae

1. Milvus migrans (Boddaert, 1783) [Tobi]

2. Accipiter gularis (Temminck \& Schlegel, 1844) [Tsumi]

Order Galliformes Phasianidae

3. Bambusicola thoracica (Temminck, 1815) [Kojukei]

4. Phasianus soemmerringii Temminck, 1830 [Yamadori]

5. Phasianus colchicus Linnaeus, 1758 [Kiji]

Order Columbiformes Columbidae

6. Streptopelia orientalis (Latham, 1790) [Kijibato]

Order Strigiformes

Strigidae

7. Otus lempiji (Horsfield, 1821) [Ôkonohazuku]

Order Passeriformes Motacillidae

8. Motacilla cinerea Tunstall, 1771 [Kisekirei]

9. Anthus hodgsoni Richmond, 1907 [Binzui] Turdidae

10. Erithacus akahige (Temminck, 1835) [Komadori]

(A)

(A; B)

(A; B; C; D; E)

(E)

11. Zoothera dauma (Latham, 1790) [Toratsugumi]

12. Turdus sibiricus Pallas, 1776 [Mamijiro]

13. Turdus cardis Temminck, 1831 [Kurotsugumi]

14. Turdus chrysolaus Temminck, 1831 [Akahara]

15. Turdus celaenops Stejneger, 1887 [Akakokko]

16. Turdus pallidus Gmelin, 1789 [Shirohara]

17. Turdus obscurus Gmelin, 1789 [Mamityajinai] Sylviidae

18. Cettia diphone (Kittlitz, 1831) [Uguisu] Aegithalidae

19. Aegithalos caudatus (Linnaeus, 1758) [Enaga] Paridae

20. Parus ater Linnaeus, 1758 [Higara]

(A)

(A)

(A; G)

21. Parus varius Temminck \& Schlegel [Yamagara]

22. Parus major Linnaeus, 1758 [Shijûkara]

Emberizidae

23. Emberiza cioides Brandt, 1843 [Hôjiro]

$(\mathrm{A} ; \mathrm{H})$

24. Emberiza rustica Pallas, 1776 [Kashiradaka]

25. Emberiza elegans Temminck, 1835 [Miyamahôjiro]

$(\mathrm{A} ; \mathrm{G})$

26. Emberiza spodocephala Pallas, 1776 [Aoji]

(A)

27. Emberiza variabilis Temminck, 1835 [Kuroji] (D; G; H) Corvidae

28. Garrulus glandarius (Linnaeus, 1758) [Kakesu]

$(\mathrm{A} ; \mathrm{D})$

A --- Asanuma et al., 1955; B --- Asanuma, 1956; C --- Asanuma et al., 1956; D --- Saito, 1959; E --- Saito et al., 1965; F --- Fujita \& Takada, 1977; G --Miyamoto et al., 1993; H -.- Ishiguro et al., 1997. Both scientific and Japanese names follow Morioka et al. (1997). 
our sincere gratitude to Dr. H. Kakuda of Fukuoka Minami Girl's High School for providing information, Ms. H. Amano (BLKU) for offering ornithological information and Dr. F. Ishiguro of Fukui Prefectural Institute of Public Health for his kindness on sending us a reference.

\section{References}

Asanuma, K., 1956. Tularemia, ticks, and mesostigmatid mites of the Far East. Ann. Prof. Rep., 406th Medical General Laboratory. pp. 91-96.

Asanuma, K., S. Ohara, N. Sakurai, H. Nakagawa, A. Goto \& T. Sato, 1956. Studies on ticks infesting source animals of Yato-byo or tularemia in Japan. Jpn. J. Sanit. Zool., 7: 127. (In Japanese)

Asanuma, K., N. Sakurai, S. Ohara, H. Odajima, K. Kosaka \& H. Nakagawa, 1955. On the host and distribution records of a tick, Haemaphysalis flava, a dominant parasite of wild hares in Japan. Misc. Rep. Res. Inst. Nat. Resour., 37: 127-128. (In Japanese)

Fujita, H. \& N. Takada, 1977. Studies on ixodid fauna in the northern part of Honshu, Japan 1. Hosts, distribution and additional case of human infestation. Jpn. J. Sanit. Zool., 28: 57. (In Japanese)

Ishiguro, F., S. Wada \& K. Inada, 1997. Isolation of Lyme Borrelia from ticks fed on birds in the Nyû Highland of Fukui Prefecture. J. Jpn. Vet. Med. Assoc., 50: 555558. (In Japanese with English summary)

Miyamoto, K., M. Nakano, H. Fujita, \& F. Sato, 1993. The ixodid ticks on migratory birds in Japan and the isolation of Lyme disease spirochetes from bird-feeding ticks. Jpn. J. Sanit. Zool., 44: 315-326.

Morioka, H. et al. (eds.), 1997. List of Japanese Birds. Jpn. J. Ornithol., 46: 59-91. (In Japanese)

Saito, Y., 1959. Studies on ixodid ticks. Part I. On ecology, with reference to distribution and seasonal occurrence of ixodid ticks in Niigata Prefecture, Japan. Acta Med. Biol., 7: 193-209.

Saito, Y., M. Kubota, A. Yajima, T. Watanabe \& K. Kamino, 1965. Studies on ixodid ticks. Part VIII. On Haemaphysalis bispinosa Neumann, 1897 in Niigata Prefecture, Japan, with some supplementary observation on bovine piroplasmosis. Acta. Med. Biol., 13: 143-159.

Yamaguti, N., V. J. Tipton, H. L. Keegan \& S. Toshioka, 1971. Ticks of Japan, Korea and the Ryukyu Islands. Brigham Young Univ. Sci. Bull. Biol. Ser., 15: 1-226. 
